\title{
Modul Simulator Pembangkitan Sinyal Pseudo Random Generator pada Sistem Komunikasi Spread Spectrum Memanfaatkan Microcontroller
}

\author{
Achmad Solichuccin, Widya Yeniari, Akuwan Saleh, Tri Budi Santoso \\ Jurusan Teknik Telekomunikasi, Politeknik Elektronika Negeri Surabaya \\ Kampus ITS, Keputih Sukolilo Surabaya \\ Telepon +62 -31-5947280 Fax +62 -31-6946114
}

\begin{abstract}
Abstrak
Sebuah modul simulator perangkat keras untuk sinyal pseudo random generator (PRG) telah dibuat dengan memanfaatkan microcontroller 8951. Dari data pengujian sistem pemancar dan bagian penerima telah menunjukkan bahwa simulator ini mampu menunjukkan 3 sifat dasar dari sebuah spreading dan despreading pada sistem direct sequence spread spectrum (DSSS), yaitu autokorelasi, balance property dan run property. Dengan input base band sebesar $4 \mathrm{kHz}$, sistem ini mampu memberikan coding gain sebesar $8,2 d B$.

Kata kunci : pseudo random generator, direct sequence spread spectrum, base band.
\end{abstract}

\section{Pendahuluan}

Salah satu pelopor di bidang teknologi komunikasi bergerak, AMPS telah menawarkan produk CDMA untuk sistem celullar[1]. Di dalam paper [2] diberikan gambaran yang sangat jelas tentang konsep teknologi spread spectrum secara mendetail.

Permasalahan yang umum dijumpai dalam penyampaian materi kuliah adalah kurangnya alat peraga, sehingga siswa dengan terpaksa harus menggunakan imaginasinya untuk memahami materi yang hanya disampaikan secara matematis sebagai bahasa pengantarnya. Trueman dalam papernya [3] memberikan gambaran sebuah modul interaktif berbasis perangkat lunak untuk transmission line.

Dalam paper ini disajikan sebuah modul simulator berbentuk prototipe perangkat keras untuk sebuah pseudo random generator (PRG) yang merupakan inti dari sebuah sistem komunikasi spread spectrum. Dengan modul berbasis prototipe perangkat keras ini diharapkan siswa lebih mudah dalam memamahi sistem.

\section{Sistem Komunikasi Spread Spectrum}

Sistem komunikasi Spread Spectrum merupakan sistem komunikasi yang mempunyai rangkaian Spreader dan De-Spreader. Proses pembentangan sinyal informasi biner dilakukan hingga spektral dayanya memiliki bandwidth lebih lebar dan menyerupai sebuah noise.
Pembentukan sinyal pada sistem Spread Spectrum menggunakan rangkaian pengacak sinyal semu (Pseudo Random) yang biasa disebut dengan Pseudo Random Generator (PRG).

\subsection{Modulasi Spread Spectrum}

Bentuk umum diagram blok sistem komunikasi direct sequence spread spectrum (DSSS) ditunjukkan pada gambar 1. Dalam hal ini kanal komunikasi dapat berupa udara, kabel, waveguide dan fiber optik. Pola PRG ini hanya dikenali oleh penerima tertentu saja.

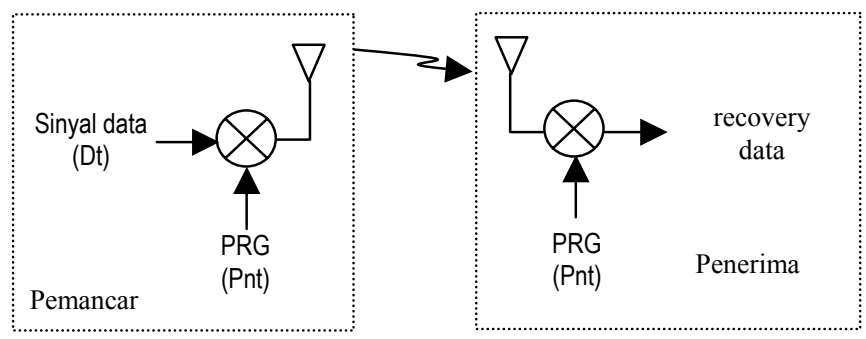

Gambar 1. Diagram blok sistem komunikasi DSSS

\subsubsection{Spreading dan De-Spreading}

Input data yang berupa data digital $D t$ yang mempunyai lebar bandwidth sempit, di-XOR dengan kode pseudo random Pnt dengan lebar bandwidth cukup besar. Hasil XOR tersebut adalah sinyal direct code spread spectrum txb, yang memiliki bandwidth lebar dan membawa kandungan sinyal digital Dt. Sinyal inilah yang akan ditransmisikan.
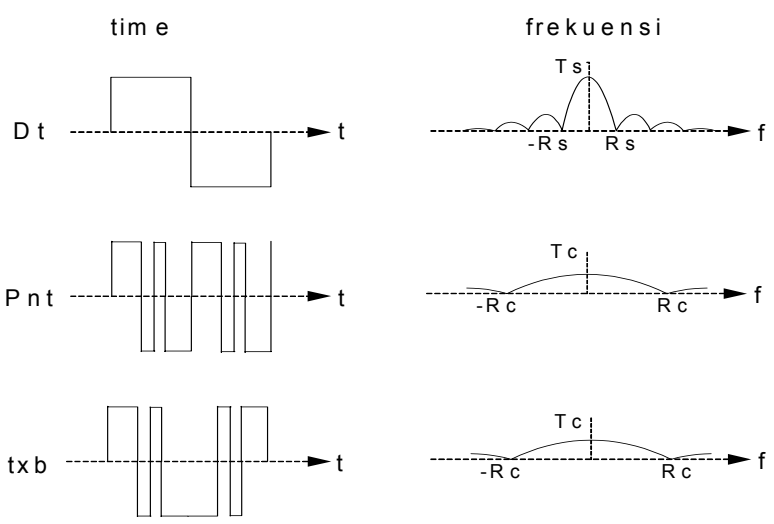

Gambar 2. Bentuk sinyal sebelum dan sesudah spreading dalam domain waktu dan frekuensi 
Sedangkan pada bagian penerima, sinyal transmisi baseband yang diterima (Rxb) akan diXOR dengan sinyal pseudo random yang sama dengan transmitter, sehingga didapatkan data informasi digital asli (proses recovery).

\subsection{Pseudo Random Generator}

Pola acak yang dibangkitkan tidak benar-benar acak, tetapi merupakan pola semi acak atau yang kita kenal sebagai pseudo random, sehingga bagian penerima dapat melakukan pembangkitan ulang untuk me-recover informasi.

Dengan teknik pembangkitan sinyal acak semu maximal-length shift register sequence akan dihasilkan sebuah pola pengacakan yang maksimum. Sinyal acak yang dihasilkan oleh shift register dari pemilihan taping yang dilakukan akan menyebabkan bentuk kode-kode yang berlainan untuk masingmasing taping.

Pada paper ini digunakan 8 shift register yang akan menghasilkan panjang sinyal psudo random 255 bit, sehingga didapatkan Pseudo Random (PRG) yang semakin panjang.

Blok diagram dari 8 shift register dapat dilihat pada gambar 3 . Untuk 8 shift register kemungkinan pemilihan taping adalah $\{[1,2,3,7][1,4,5,7][2,4,5,7]$ $[0,2,5,7][0,4,5,7][0,5,6,7]\}$. Pada program yang dibuat digunakan taping $[1,2,3,7][1,4,5,7][2,4,5,7]$ $[0,2,5,7]$.

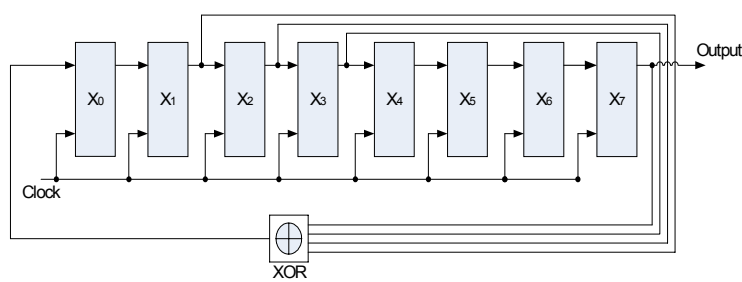

Gambar 3. Sekuen Shift Register 8-stage taping-1237

\section{Sifat-Sifat Random}

Tiga sifat dasar untuk mengetahui apakah sekuen biner dapat memenuhi kriteria random adalah:

1. Balanced Property : kondisi balance (seimbang) untuk sekuen biner yang baik men-syaratkan jumlah bit 1 dan jumlah bit 0 yang muncul sama. Beda yang diijinkan maksimum adalah 1 digit.

2. Correlation Property : jika suatu periode pada suatu sekuen dibandingkan secara term by term dengan suatu siklus yang digeser terhadap dirinya sendiri, akan di dapat suatu kondisi dimana sinyal itu akan memiliki perulangan. Sinyal ini memiliki nilai korelasi 1 jika kedua sinyal bebar-benar mirip.

3. Run Property : artinya deretan chip dari logika yang sama dalam satu periode kode biner acak. Pada setiap setengah dari jumlah chip untuk logika yang sama $(\mathrm{m})$ dalam satu periode memiliki rentang run $1 / 2$ dari jumlah chip $(0.5 \mathrm{~m})$ sebanyak satu, memiliki rentang run $1 / 4$ jumlah chip $(0.25 \mathrm{~m})$ sebanyak dua, memiliki rentang run $1 / 8$ jumlah chip $(0.125 \mathrm{~m})$ sebanyak tiga, dan seterusnya. Jumlah run untuk sinyal berlogik satu sama dengan jumlah run untuk sinyal berlogika nol.

\subsection{Gain Proses}

Salah satu dari karakter sistem komunikasi spread spectrum adalah adanya gain proses yang merupakan besarnya perbandingan antara jumlah bit rate hasil proses spreading (chip rate) dengan bit rate informasi (data rate).

Besar Gain Proses (dB) dapat dihitung :

$$
\begin{aligned}
& P g=10 \log \left[\frac{W s s}{R}\right](d B) \quad ; \text { Ws } \approx R c h \\
& \text { maka } \\
& P g=10 \log \left[\frac{R c h}{R}\right](d B)
\end{aligned}
$$

dimana:

Wss = lebar pita Spread Spectrum

$\mathrm{R}=$ kecepatan data informasi (data rate)

$\mathrm{Rch}=$ kecepatan sinyal acak (chip rate)

\section{Perencanaan Dan Pembuatan Perangkat \\ 3.1 Perancangan Perangkat Keras}

Perangkat keras dibagi menjadi dua rangkaian utama, yaitu rangkaian pemancar sebagai spreader (pengacak data) dan rangkaian penerima sebagai despreader (recovery data). Kedua rangkaian tersebut disusun dari minimum sistem mikrokontroller AT 89C51 sebagai pembangkit Pseudo Random Generator (PRG) dengan tombol pemilihan untuk variasi taping dan clock PRG (DIP switch), buffer (IC 74LS244) sebagai penguat sinyal PRG, IC XOR (74LS86) sebagaimana terlihat pada gambar 4.

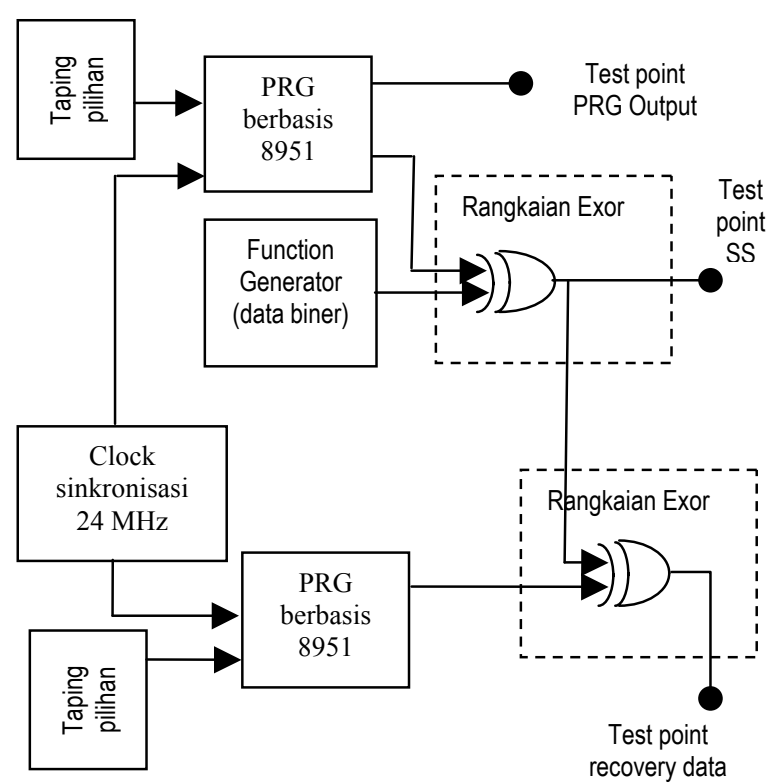

Gambar 4. Blok diagram rangkaian simulator 


\subsection{Perancangan Perangkat Lunak}

Perangcangan perangkat lunak dilakukan dengan menggunakan simulator 8051. Dengan mengacu pada diagram alir seperti pada Gambar 5 sebuah PRG akan disusun. Apabila program yang disimulasikan telah menunjukkan hasil yang benar, selanjutnya dilakukan beberapa modifikasi untuk menyesuaikan dengan hardware yang digunakan dan program yang sudah jadi dalam bentuk assembler code di-download ke eprom yang ada di 8951. Karena program yang disusun sangat sederhana maka dalam kasus ini tidak diperlukan external eprom, dan cukup menggunakan internal eprom yang ada di 8951.

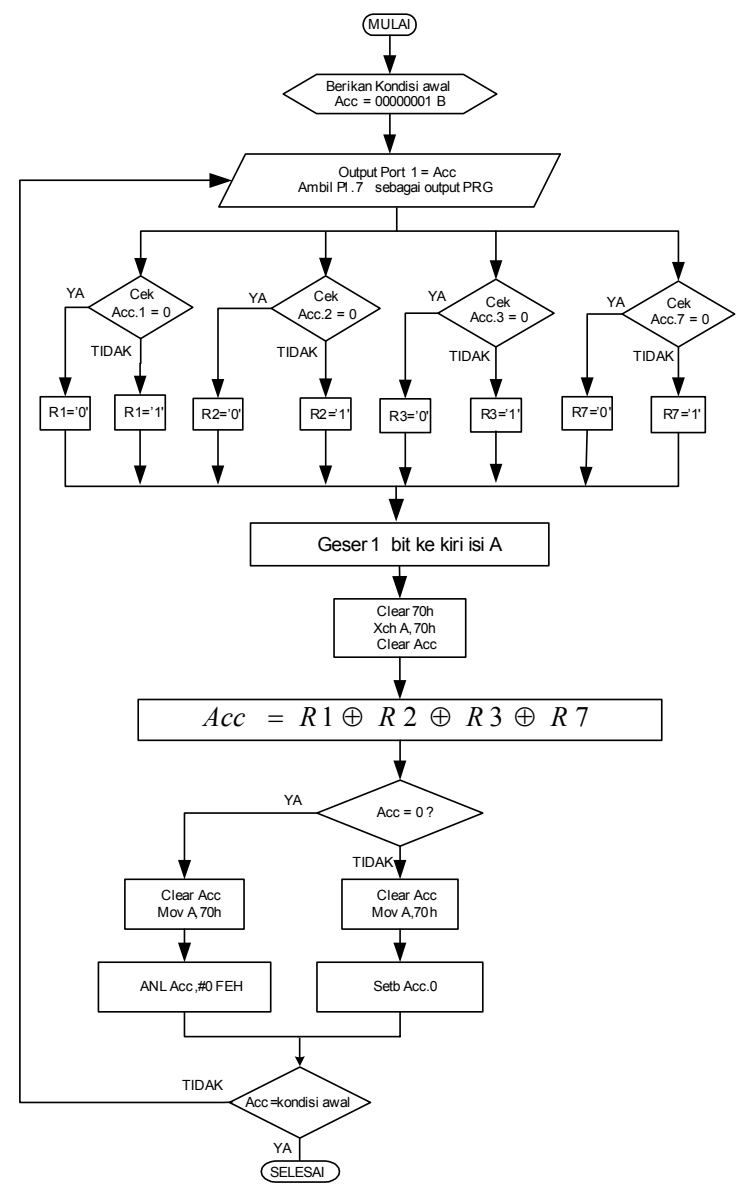

Gambar 5. Diagram alur program PRG

\section{Pngujian Sistem}

\subsection{Penataan Pengujian Perangkat}

Untuk pengujian prototipe yang telah dibuat sistem harus ditempatkan dengan mengacu pada blok diagram Gambar 4. Dalam realisasinya diperlukan function generator sebagai pembangkit data biner, dan sebuah digital storage oscilloscope untuk mengamati sinyal. Untuk pengukuran spektrum belum dilakukan pada penelitian ini. Lebih jelasnya dapat dilihat pada Gambar 6 berikut ini.

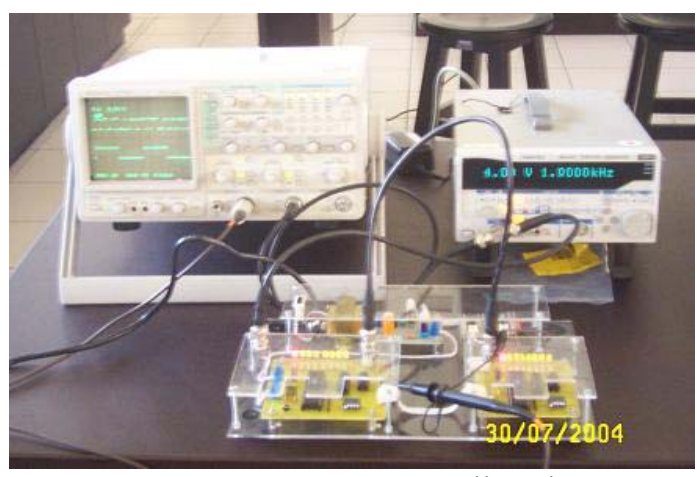

Gambar 6. Penataan pengujian sistem

\subsection{Pengukuran Sinyal Terbangkit}

Pengukuran sinyal terbangkit dari function generator sebagai sinyal data dan sinyal output dari exor ditujukan untuk mengetahui bagaimana pengaruh PRG pada sistem yang dirancang. Dengan menggunakan input data sebesar $4 \mathrm{kHz}$ didapatkan hasil pengukuran seperti Gambar 7.

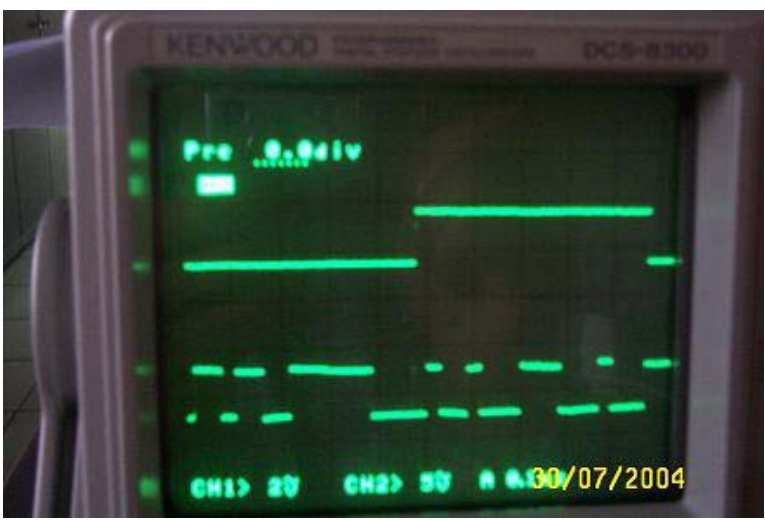

Gambar 7. Perbandingan sinyal data dengan hasil spreading

Bagian atas pada gambar merupakan sinyal asli dari function generator, sedangkat bagian bawah merupakan sinyal hasil proses spreading.

Sinyal yang telah diberi perlakuan spreading selanjutnya dikirimkan secara wireline dengan kabel coaxial ke bagian penerima. Untuk mengetahui apakah sistem penerima bisa bekerja maka dilakukan pengukuran sinyal recovery yang merupakan output pada bagian penerima. Sinyal ini dibandingkan dengan sinyal input asli pada pemancar. Bagian atas pada Gambar 8 merupakan sinyal asli dari function generator, sedangkan bagian bawah merupakan hasil recovery pada penerima. 


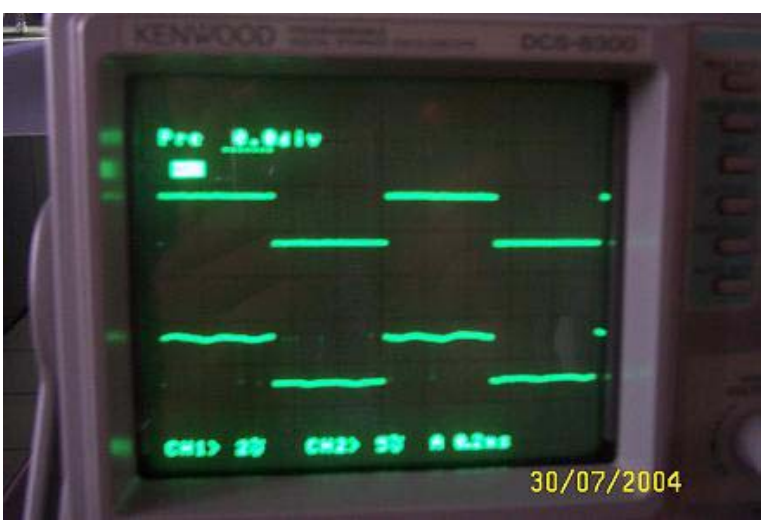

Gambar 8. Perbandingan sinyal asli pada pemancar dengan hasil recovery pada penerima

Untuk memastikan bahwa sistem yang dirancang berjalan benar pilihan taping pada bagian pemancar dibuat berbeda dengan bagian penerima. Hal ditujukan untuk menguji apakah dengan pemilihan taping berbeda bagian penerima tidak akan mampu mengolah sinyal kembali seperti aslinya. Pada saat taping bagian pemancar dipilih [1,2,3,7] dan bagian penerima $[1,4,5,7]$ memberikan hasil seperti pada Gambar 9.

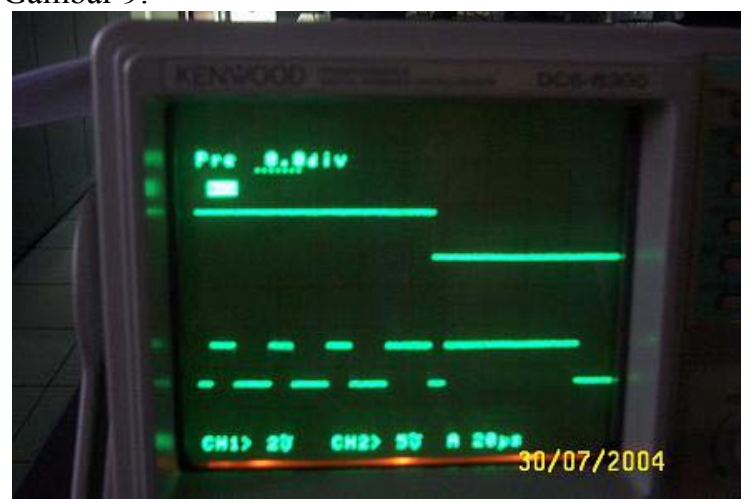

Gambar 9. Pengaruh perbedaan pemilihan taping pada pemancar dan penerima.

\subsection{Pengujian Sifat Dasar PRG}

\section{- Pengujian Balalce Poperty}

Untuk melakukan pengujian Balanced Property dilakukan perhitungan jumlah logika ' 1 ' dan ' 0 ' pada masing-masing taping. Untuk itu perlu dibuat tabel dari data yang dihasilkan. Setelah penghitungan terhadap tabel tersebut, didapatkan pada taping-1237, taping-1457 dan taping-2457 jumlah logika ' 0 ' pada masing-masing taping adalah 127. Dan jumlah logika ' 1 ' pada masing-masing taping adalah 128. Untuk taping-0247 jumlah logika ' 0 ' adalah 98 dan jumlah logika '1' adalah 104.

Tabel 1 Contoh data pseudo random (taping-1237)

\begin{tabular}{|l|l|l|l|l|}
\hline \multicolumn{5}{|c|}{ Data Output Taping-1237 } \\
\hline 00000001 & 01100011 & 11010000 & 11111111 & 00100001 \\
\hline 01001111 & 10101010 & 11100000 & 11000101 & 01100110 \\
\hline 01011111 & 10111100 & 11011101 & 11001010 & 10010100 \\
\hline 01001011 & 01000110 & 01110011 & 11000110 & 11000010 \\
\hline
\end{tabular}

\begin{tabular}{|l|l|l|l|l|}
00101110 & 10111101 & 10111110 & 00011010 & 01101011 \\
\hline 01101010 & 00001001 & 11011001 & 00100110 & 00000111 \\
\hline 01001000 & 1110001 & & & \\
\hline
\end{tabular}

Berdasarkan hasil perhitungan tersebut dapat disimpulkan bahwa pseudo random pada taping1237, taping-1457 dan taping-2457 telah memenuhi syarat balanced property sehingga dapat digunakan sebagai pengacak sinyal.

\section{- Pengujian Correlation Property}

Pengujian ini dilakukan dengan cara mencari yang disebut autocorrelation dari pseudo random yang telah dihasilkan.

Pengujian autocorrelation tersebut dilakukan dengan menggunakan perangkat lunak Matlab. Data yang dihasilkan dari modul direcord, dan selajutnya disimpan dalam bentuk file *.txt. Dengan perangkat lunak Matlab dilakukan pengujian sifat korelasinya. Dari pengujian didapatkan grafik bentuk korelasi seperti pada Gambar 10.

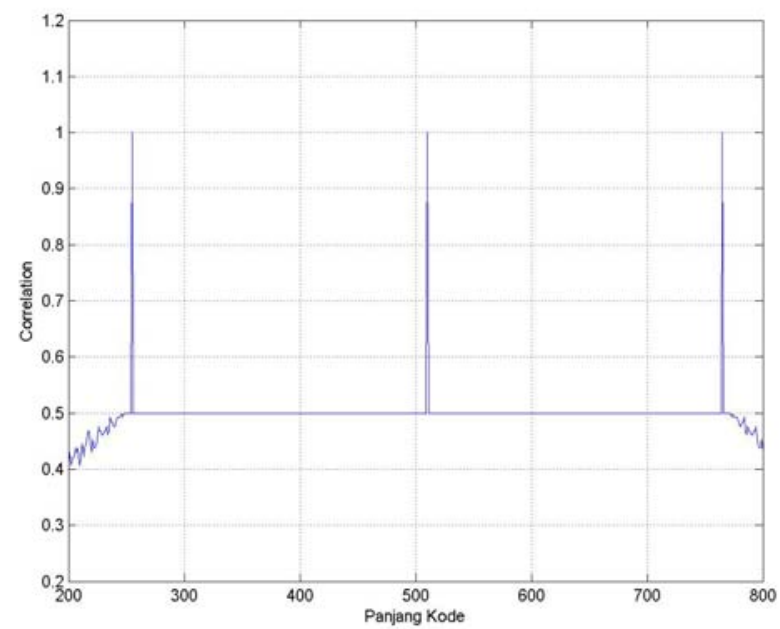

Gambar 10. Sifat auto korelasi

Seperti pada gambar diatas di atas, data masukan memiliki panjang kode 255, sehingga autocorrelation juga akan terjadi pada panjang kode 255 yang ditunjukkan dengan nilai 1 pada saat panjang sinyal 255.

Nilai ini terus terjadi berulang-ulang sebanyak perulangan yang terjadi pada perulangan data masukan. Pada grafik menunjukkan terjadi autocorrelation sebanyak tiga kali sesuai perulangan data masukan. Panjang kode yang terjadi juga sama dengan panjang kode aotucorrelation yang pertama, yaitu 255. Jadi, jika auocorrelation pertama terjadi pada panjang kode 255 , maka untuk autocorrelation yang kedua terjadi pada saat panjang kode $2 * 255=$ 510. Begitu juga untuk autocorrelation yang ketiga, akan terjadi pada kelipatan 255, yaitu pada saat panjang kode $3 * 255=765$. 


\section{- Penguiian Running Property}

Pada pengujian Run Property akan menggunakan tabel distribusi run untuk deretan $2^{8}-$ 1 sebagai tabel kebenaran.

Tabel 2 Distribusi Run Deretan $2^{8}-1$ chip

\begin{tabular}{|c|c|c|c|}
\hline \multirow{2}{*}{$\begin{array}{c}\text { Rentang } \\
\text { run } \\
\text { (chip) }\end{array}$} & \multicolumn{2}{|c|}{ Jumlah run } & \multirow{2}{*}{$\begin{array}{c}\text { Jumlah chip } \\
\text { keseluruhan }\end{array}$} \\
\cline { 2 - 3 } & "0" & "1" & \\
\hline 1 & 32 & 32 & 64 \\
\hline 2 & 16 & 16 & 64 \\
\hline 3 & 8 & 8 & 48 \\
\hline 4 & 4 & 4 & 32 \\
\hline 5 & 2 & 2 & 20 \\
\hline 6 & 1 & 1 & 12 \\
\hline 7 & 1 & 0 & 7 \\
\hline 8 & 0 & 1 & 8 \\
\hline Total & 64 & 64 & 255 \\
\hline
\end{tabular}

Jumlah run yang dicari hanya terdiri dari dua logika, yaitu ' 0 ' dan ' 1 '. Dengan menentukan ' 0 ' atau ' 1 ' dan melihat rentang run maka akan diperoleh jumlah run-nya. Maksudnya, logika ' 0 ' dan ' 1 ' dengan rentang run 1 akan terjadi perulangan sebanyak 32 kali. Dan logika ' 0 ' dan ' 1 ' pada rentang run 2 akan terjadi perulangan sebanyak 16 kali pada pseudo random. Dan begitu seterusnya. Setelah diketahui jumlah run pada masing-masing rentang run maka akan didapatkan jumlah chip keseluruhan. Jumlah chip pada setiap rentang run dapat dicari dengan mengalikan jumlah run pada tiap-tiap logika ('0' dan ' 1 ') dengan rentang run-nya. Hasil perkalian dari setiap logika tersebut dijumlahkan. Setelah setiap rentang run dicari jumlah chip, maka jumlah chip keseluruhan dapat dicari. Jumlah chip keseluruhan ini merupakan jumlah chip pseudo random dalam satu periode.

Dan setelah dilakukan pengujian, untuk taping1237, taping-1457 dan taping-2457 run property sesuai dengan yang terdapat pada tabel. Sedangkan untuk taping-0247, run property tidaklah sesuai. Hal ini menyebabkan pseudo random pada taping-0247 tidak memenuhi syarat sebagai pengacak sinyal. Selain pada run property, pada balanced property taping-0247 juga tidak memenuhi syarat.

\subsection{Analisa Gain Proses}

Pengujian gain proses dilakukan dengan cara membandingkan chip rate dengan data rate dengan catatan sinyal output dari pemancar masih dalam bentuk acak dan sulit dikenali dengan penerima biasa.

Pada modul yang disusun disini sinyal informasi diawali dengan nilai sebesar $1 \mathrm{kHz}$, atau secara perhitungan akan menghasilkan nilai grin proses $(\mathrm{Pg})$ sebesar:

$$
P g=10 \log (R \operatorname{ch} / R)=10 \log (26,3 / 1)=14,2 \mathrm{~dB}
$$

Dari hasil pengamatan bentuk sinyal dengan oscilloscope memberikan hasil bahwa proses spreading (pengacakan) dapat dihasilkan.

Berikutnya nilai data rate dari function generator dinaikkan dengan nilai $2 \mathrm{KHz}, 3 \mathrm{KHz}, 4 \mathrm{KHz}$ sampai dengan $9 \mathrm{KHz}$ atau dalam perhitungan gain proses memiliki nilai sebesar: $11,2 \mathrm{~dB}, 9,4 \mathrm{~dB}, 8,4 \mathrm{~dB}$, sampai $4.7 \mathrm{~dB}$. Pada nilai-nilai tersebut PRG yang disusun mampu memberikan pengaruh spreading dan output dati pemancar masih relatif dalam kondisi teracak. Tetapi pada saat nilai data input dinaikkan menjadi $20 \mathrm{KHz}$ dan seterusnya, maka efek pada proses spreading tidak lagi dapat dilihat.

Dengan mengacu pada bandwidth sinyal voice sebesar $4 \mathrm{KHz}$, maka dapat dikatakan bahwa sebagai modul simulator sistem hasil perancangan ini cukup memenuhi persaratan untuk PRG karena sudah memberikan gain proses sebesar $8,4 \mathrm{~dB}$.

\section{Kesimpulan}

Dari pengujian dan analisa terhadap sistem yang telah dibuat dapat diambil kesimpulan bahwa modul ini cukup memenuhi syarat sebagai simulator pembangkit sinyal pseudo random generator:

- menunjukkan sifat balance property untuk nilai taping-1237, taping-1457 dan taping-2457

- menunjukkan sifat auto korelasi pada setiap panjang kode 255 .

- mampu menunjukkan sifat run property pada taping-1237, taping-1457 dan taping-2457.

\section{Referensi}

1. ___ ,White Paper, Spread Spectrum Wireless Technology", Wi-LAN Inc.

2. Bernard Sklar, "Digital Communications Fundamentals and Applications", 2-nd Edition, Prentice-Hall, Inc, new Jersey 07458, 2001.

3. Trueman, "Interactive Transmission Line Computer Program for Undergraduate Teaching", IEEE Transaction on Educations, Vol. 43, No 1, February 2000.

4. Atmel, "Flash Microcontroller : Architectural Overview", Atmel. Inc (http://www.atmel.com), USA, 1997.

5. Atmel, "AT 89 Series Hardware Description", Atmel. Inc (http://www.atmel.com), USA, 1997 